\section{Conceptual Hybrids: Type in the 1990s}

Rick Poynor,

\author{
Eye and Print magazines; Royal College of Art, London
}

In the early to mid-1990s, forward-thinking graphic designers focused on type design to a degree that might in retrospect seem curious or even misguided. Lettering artists and specialist typographers have always created an enormous variety of display types for use on posters, advertising and packaging, but the new concept-driven typeface design was something quite different from this purely decorative tendency. Few of the more outlandish fonts were created with use primarily in mind. Instead, for a time, the alphabet became the focus for an urge to experiment inspired by the new digital technology, desktop computers and software programs, that reflected, in the most spectacular fashion, a wider sense of change in society, communication and the media. Today, we can best understand these extreme manipulations, which burst the bounds of legibility, by seeing them as illustrations of the era of burgeoning possibility in which they were invented.

"Conceptual type" is not, however, a designation that enjoyed any currency during that comparatively brief phase of experiment. Nor is the term widely in use today, either to describe the historical phenomena I concentrate on here, or in contemporary type design. The second edition of Robin Kinross's Modern Typography: An Essay in Critical History, an essential study, makes no reference to conceptual type, not even in the section titled "Legibility Wars", which deals with the same period discussed in this essay (Kinross 2004: 172-4). There is, however, a brief section devoted to "Conceptual Alphabets \& Lettering" in Lettering \& Type, a guidebook by Bruce Willen and Nolen Strals, although they don't discuss the history of conceptual alphabets and show only a handful of recent examples. They write:

“Conceptual letters or alphabets rarely aim to create the most readable text, and their letterforms occasionally lack recognizably alphabetic characteristics. Instead, conceptual alphabets illustrate or embody ideas, sets of constraints, and editorial perspectives, illustrating their concepts through letterforms rather than strictly pictorial means. [...] What sets conceptual letters apart is a rigid adherence to their guiding principles above other concerns. [...] Conceptual letters are dedicated to their idea above all else" (Willen \& Strals 2009: 22)

If conceptual type remains a relatively marginal term within type design and graphic design, conceptual art has maintained its currency as a form of art practice since the 1960s, when the term was first used to describe a rigorous, non-visual art that puts all its emphasis on the idea. To define their territory of interest, the organizers of "Conceptual Type Type Led by Ideas" resorted to a famous definition of conceptual art by the American artist Sol Lewitt, published in Artforum in 1967:

\begin{abstract}
"In conceptual art the idea or concept is the most important aspect of the work. When an artist uses a conceptual form of art, it means that all of the planning and decisions are made beforehand and the execution is a perfunctory affair. The idea becomes a machine that makes the art"
\end{abstract}

While it might be possible to create type within such a restrictive framework, this definition of conceptual art cannot adequately account for the directions and concerns seen in the conceptual type of the 1990s. Type design is a finicky craft in which the smallest details require the most attentive care. It is hard to imagine a successfully realized typeface (of any kind) where the execution is merely perfunctory, as Lewitt puts it. Nor does conceptual art's lack of concern with visual form offer type designers much room for aesthetic manoeuvre. In type design, the minutely calculated formal differences between one typeface and the next are everything. Conceptual type might still have value as a term to describe "type led by ideas", but a view of the activity determined by the theories and history of conceptual art is of limited usefulness when discussing experimental type design in the 1990s.

\section{THE DISTURBANCE OF FORM}

I want to focus now on one insistent theme in 1990s conceptual type: the idea of the hybrid letterform constructed, like Frankenstein's monster, from 


\section{Dead History}

Dead History by P. Scott Makela

pre-existing parts. Initially, these typefaces were stitched together from elements removed from other typefaces. The first well-documented instances are P. Scott Makela's Dead History and Jonathan Barnbrook's Prototype (both 1990) and Max Kisman's Fudoni (1991) (Poynor \& Booth-Clibborn 1991: 208-9). Makela's hybrid combines elements of the serif typeface Centennial and the sans serif VAG Rounded, while Kisman's similar looking font fuses Futura and Bodoni. Barnbrook's typeface, designed from 1987 to 1990, is more elaborate and collages parts from around 10 faces, including Gill, Perpetua, Futura and Bembo. For Barnbrook, this creative procedure was a conscious attempt to apply the principle of sampling, widespread in 1980s pop music, to typeface design, and he made early sketches for the face by hand. "The technology was very limited so the only thing I could do was scan and draw," he writes. "It was important though that the sampling was evident in the final font, so I made the collage feel integral to the look" (Barnbrook 2004: 44). Later, he digitized the font.

All three typefaces, with their abrupt shifts in thickness and weight within a single letter, have a peculiar and disturbing visual rhythm when composed

\section{PKOTOTYPE}

Prototype by Jonathan Barnbrook

into words and sentences. This ungainliness is exacerbated in Prototype by the fusion of uppercase and lowercase, as well as serif and sans serif, in a single character; the oddest letter is the $\mathrm{R}$, where a section of the capital's curve is cut away to form the lowercase. The hybridizing principle seen in these typefaces might appear to be entirely postmodern, but if the fonts exhibit the symptoms of an inescapable cultural condition, they also represent critical reactions against it. Makela makes the sense of exhausted history, diminished options and even failed utopia aggressively explicit in his typeface's name: Dead History. Barnbrook responds to the identity crisis that comes from operating in the ideological vacuum left behind by the failure of modernism by positing Prototype's "tired familiarity" ironically as a "revolutionary" universal replacement for the Western alphabet (Barnbrook 2007: 45).

In the early 1990s, many similar experiments by other designers followed these typefaces, which

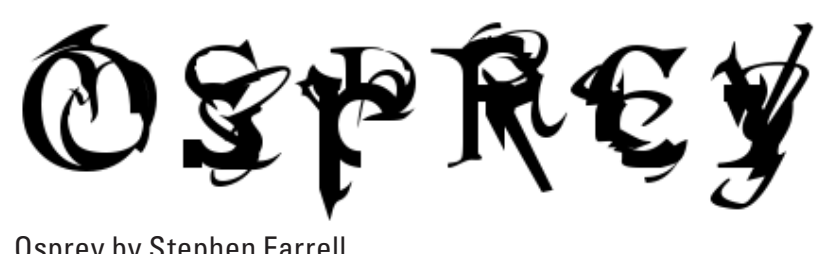

Osprey by Stephen Farrell

came to look comparatively restrained alongside their more extreme successors. Typeface names also became increasingly important in signalling a typeface's conceptual intent and its positioning in relation to other faces. In the American designer Stephen Farrell's Entropy (1992), fragments of uppercase and lowercase conjoin within a single character, but unlike in Dead History or Prototype, they fail to cohere. It is as though the graft hasn't entirely taken and the constituent parts, unable to resist the corrosion of entropy, are beginning to separate. Farrell's Osprey (1993) takes this even further (Heller \& Fink 1997: 28). The letters are still recognizable, but the outlines are bent, twisted and mutilated by sharp blades and spurs that form uncontrollable offshoots. Each character is a jittery field denoting the letter it stands for, while threatening to collapse into chaos.

It is not just consistent alphabetic structure that appears to be unravelling in these conceptual hybrids, but the bonds of language and the sustained, intelligible communication that language makes possible. Experimental typeface design in these years reflected the assumption absorbed - often secondhand - from critical theory and the critical method known as deconstruction that language was unstable and there could be no fixed or final meanings. ' In the 1980s, a similar idea had taken hold of architectural form in the tendency called deconstructivist architecture. "The dream of pure form has been disturbed," noted the critic Mark Wigley. "Form has become contaminated" (Johnson \& Wigley 1988: 10). One would not even need to see Elliott Earls's distressed and mutated trio of typefaces, Dysphasia, Dysplasia and Dyslexia (1995), to understand from their names alone that something was pro- 
foundly amiss with these fonts. ${ }^{2}$ The everyday word "dyslexia" makes the difficulties of communication obvious, but the other two names suggest more pronounced forms of damage and communicative dysfunction. Dysphasia is the condition of cognitive impairment often experienced by people who have suffered a stroke: they may have difficulty talking, listening, understanding or writing. Dysplasia, a term used in pathology, indicates a pre-cancerous change and abnormality in cells and tissues. It is hard to conceive of many functional uses for typefaces that so dramatically enact their own breakdown. These fonts are better understood as provocative propositions about contemporary culture: the conceptual typeface as autonomous art work.

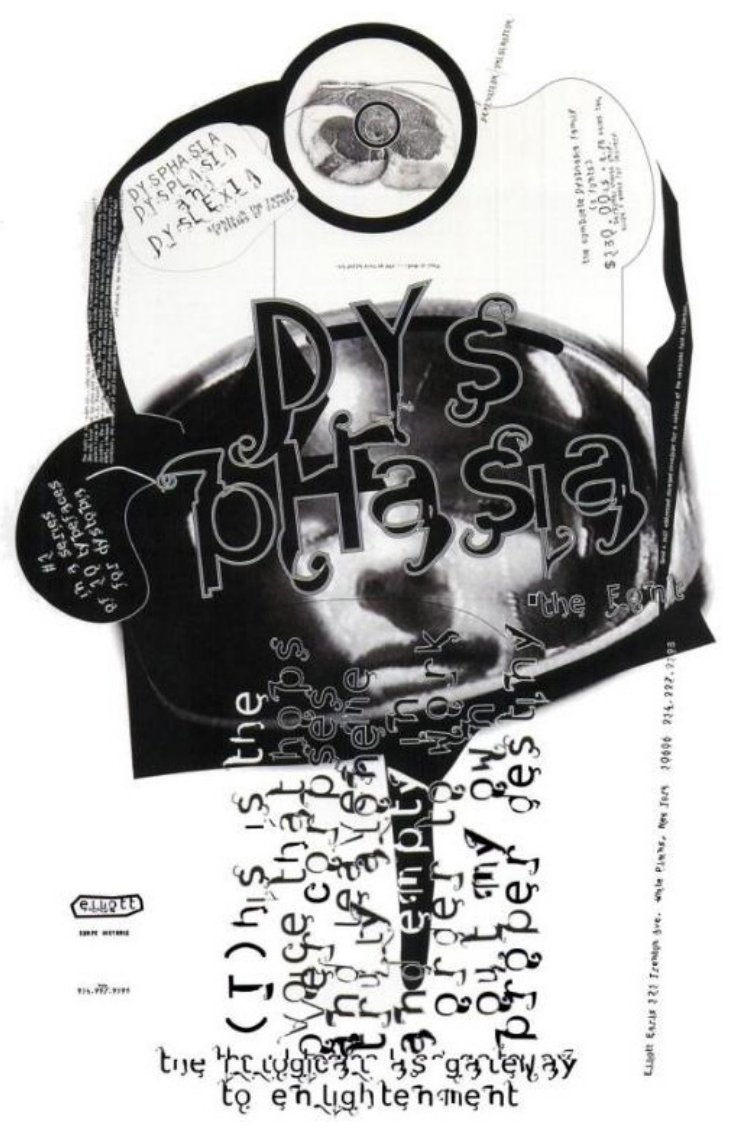

Dysphasia by Elliott Earls images. A spectacular early example is the Gothic alphabet engraved on copper in 1499 by the South German master known only as E.S. Each letterform is a miniature arabesque composed of human figures, animals and birds in bizarre and often violent relationships, yet despite the intricate internal detail, the letters maintain tightly defined angular outlines and each character is perfectly legible. In the 19th century, the lettering artist Jean Midolle created pictorial alphabets strongly reminiscent of designs by the master E.S. One set of characters, shown in Works by Jean Midolle engraved on stone and published at the lithographic press of Emile Simon the younger, published in Strasburg in 1834, is built from sections of Gothic architecture adorned by the occasional dragon, gargoyle, snake or angel (Massin 1970: 92-93). Intricate devices like these bear an obvious

\section{OBJECTS OF SURREAL FANTASY}

Here, we should recall that there is a long tradition of constructing artistic letterforms from pictorial
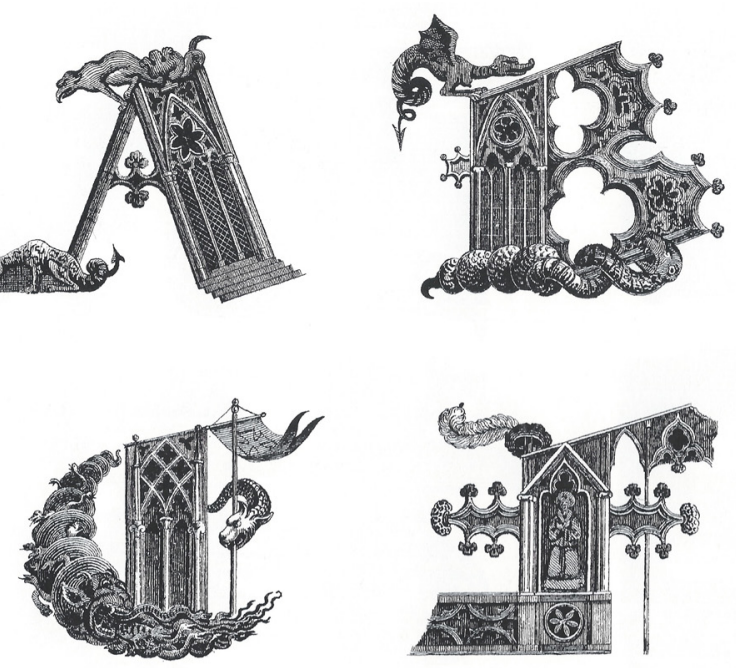

Gothic alphabet by Jean Midolle (excerpt)
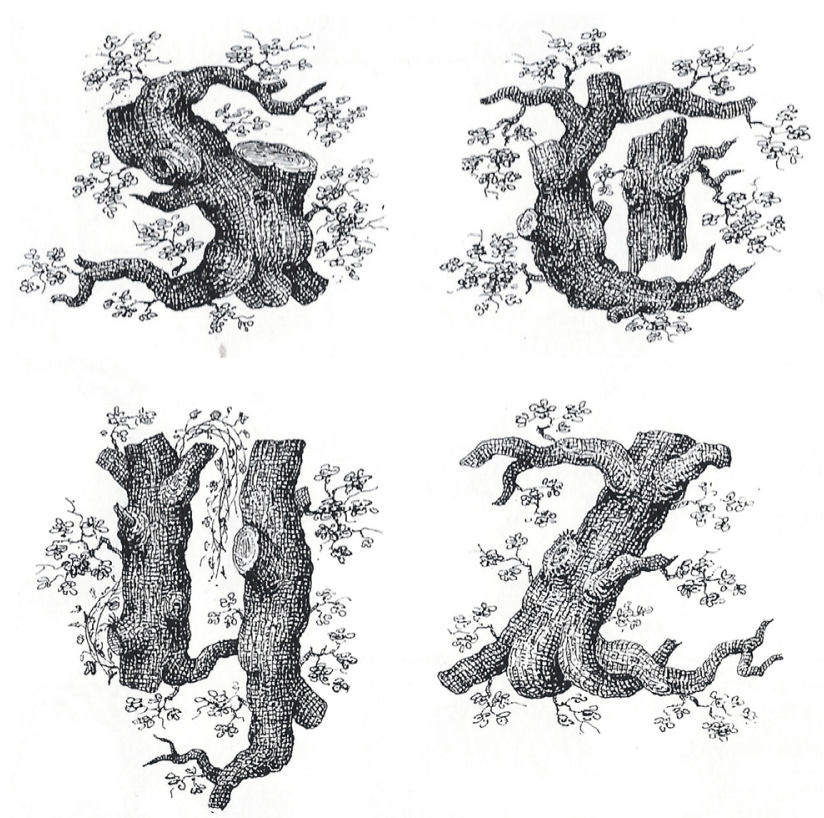
kinship with the decorative initials found in medieval illuminated manuscripts.

Forest alphabet by Jean Midolle (excerpt) 

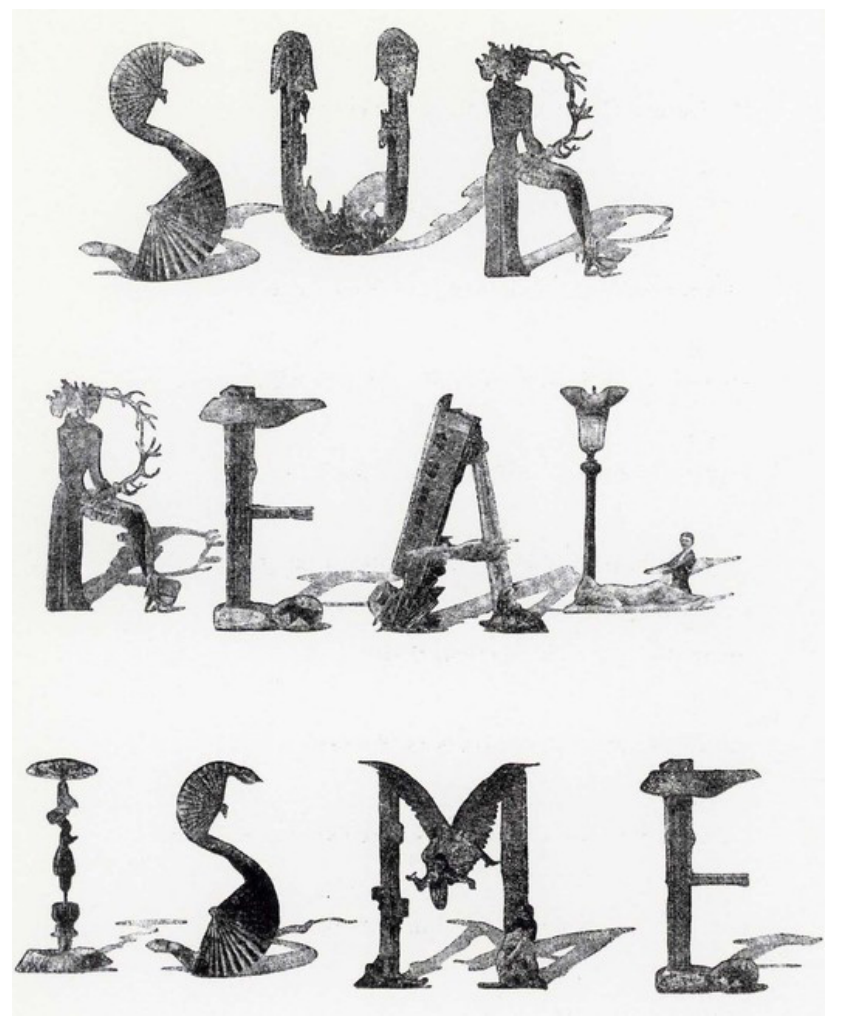

Surrealist alphabet by Jindřich Heisler

Today we would also be quick to perceive the surrealism inherent in the strange juxtapositions and transformations that elevate otherwise ordinary letterforms into objects of fantasy. In the 1930s, the surrealists were fascinated by Midolle's inventions. An article by Max Ernst titled "The Mysteries of the Forest" in Minotaure no. 5 (1934) is illustrated with an alphabet by Midolle constructed entirely from engravings of branches and tree trunks (ibid.: 86). A number of his letterforms, including characters taken from the Gothic architecture and forest alphabets, appear in André Breton and Paul Eluard's Dictionnaire abrégé du surréalisme (1938) to mark the beginning of the book's alphabetical sections.

Midolle's alphabets apply the same pictorial logic and internally consistent use of imagery to each letter. In 1952, the Czech surrealist poet and artist Jindřich Heisler created an alphabet wholly based on the surrealist principle of poetic chance encounter, with each letter collaged from its own unique components taken from engravings (Poynor 2010: 104-5). The left-hand stem of the $A$ is an old-fashioned train carriage, the $B$ consists of cog wheels and a female figure from Max Ernst's painting The Equivocal Woman, and the cross bar of the $C$ is made from hands clasping bottles and a wine glass. Each character is a one-off, cut out of a piece of plywood about $13 \mathrm{~cm}$ high, so should we regard these pieces as lettering or sculpture? In 1964, the Polish
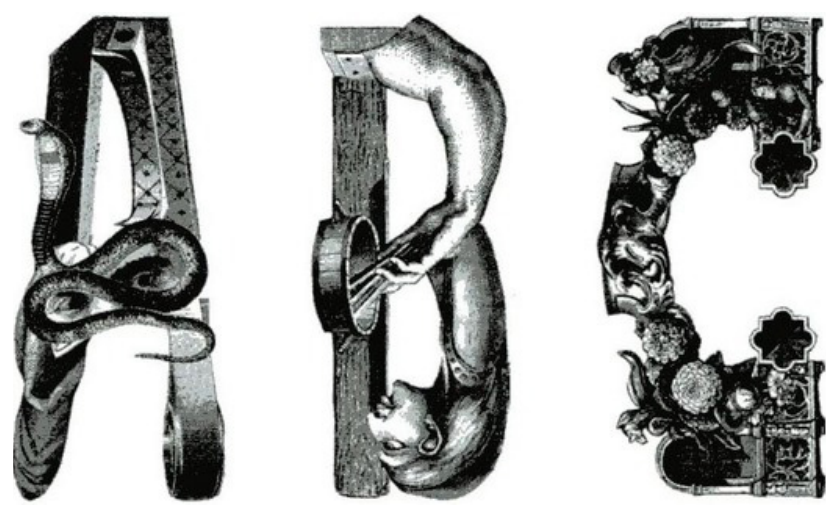

Alphabet by Roman Cieslewicz

designer Roman Cieslewicz created a similar alphabet for print purposes, also based on details from old engravings, which he assembled in startling juxtapositions for use as full-page section-openers in the book Guide de la France mystérieuse (Rouard-Snowman 1993: 40-1). Cieslewicz's alphabet was shown in a monograph published in 1993 and it was perhaps in those pages that the American designer David Carson saw it. Carson used six of the characters for the masthead of issue 11 of the rock magazine Ray Gun magazine in the same year. In this inspired coming together of surrealism and the era of desktop computer technology, the similarity between fanciful earlier alphabetic manipulations and digital designers' conceptual interest in hybrid forms of typeface becomes clear.

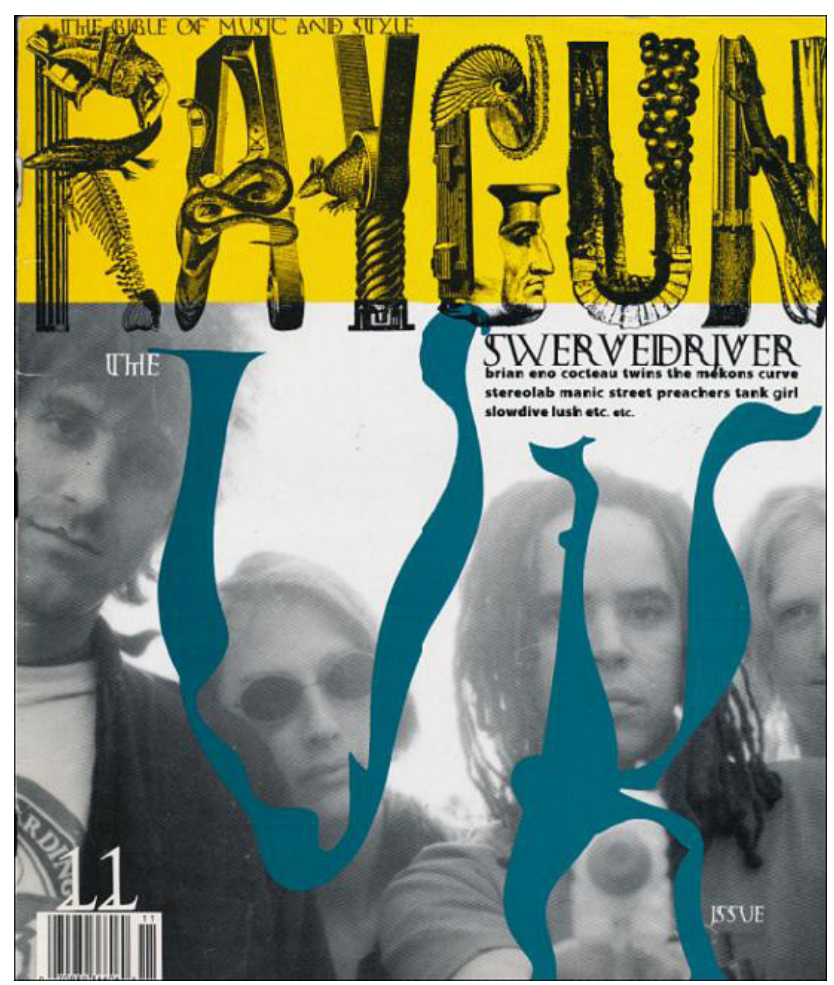

Cover of Ray Gun no. 11 by David Carson 


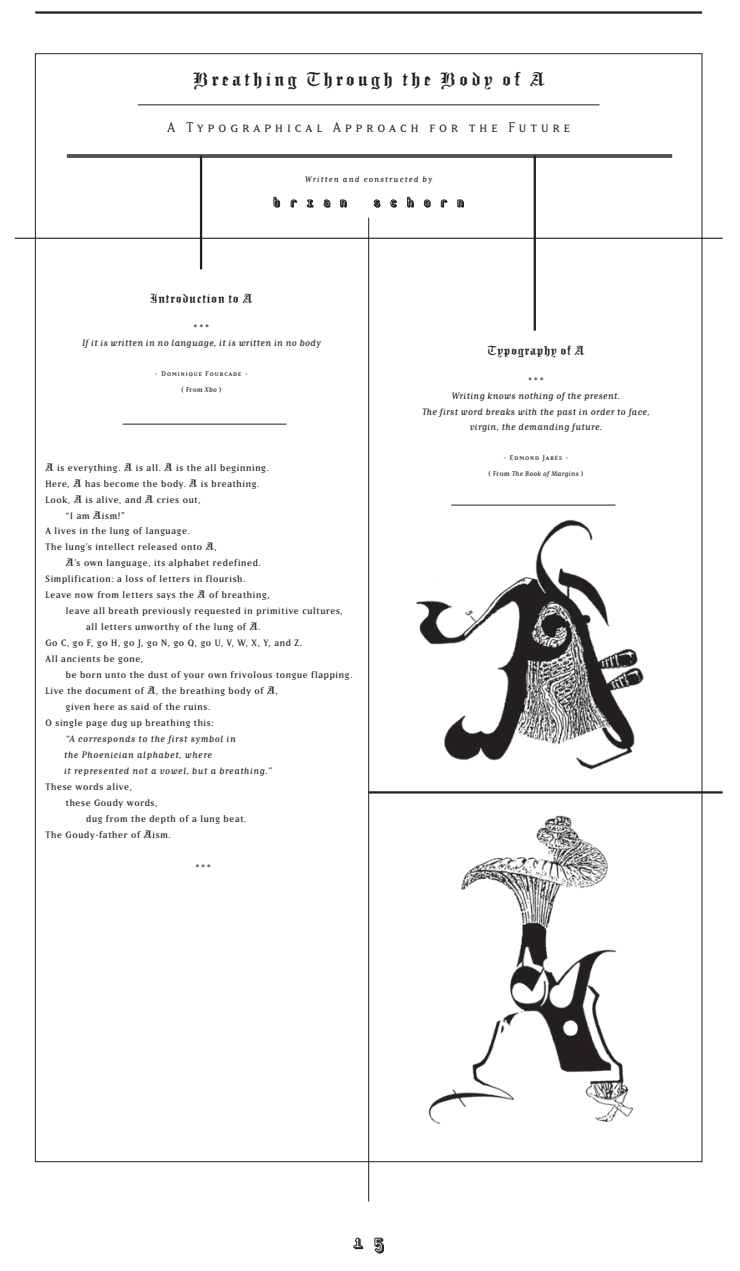

The themes under discussion here - conceptual type in the 1990s, hybridity and surrealism - find perhaps their most complete expression in the work of another American designer, Brian Schorn, then a mature MFA student at Cranbrook Academy of Art. Schorn had studied at medical school for two years before turning to photography, creative writing and then graphic design. He was fascinated by surrealism and its ideas about the unconscious, kept a dream diary and experimented with automatism and collage; he also wrote poetry (Poynor 2007: 60). He regarded the letterform as a highly pliable container with endless potential for artistic reconstruction. In a letter he wrote to me in 1995, he explained:

Although the computer aids in certain design tasks, much as the technology of lasers aids the surgeon, ultimately the hand and eye are the primary tools.

Type becomes a specimen, not on the sheet, but on the operating table. Letters can now be explored as living, organic wonders by removing old tissues, transplanting new organs, or grafting new limbs.

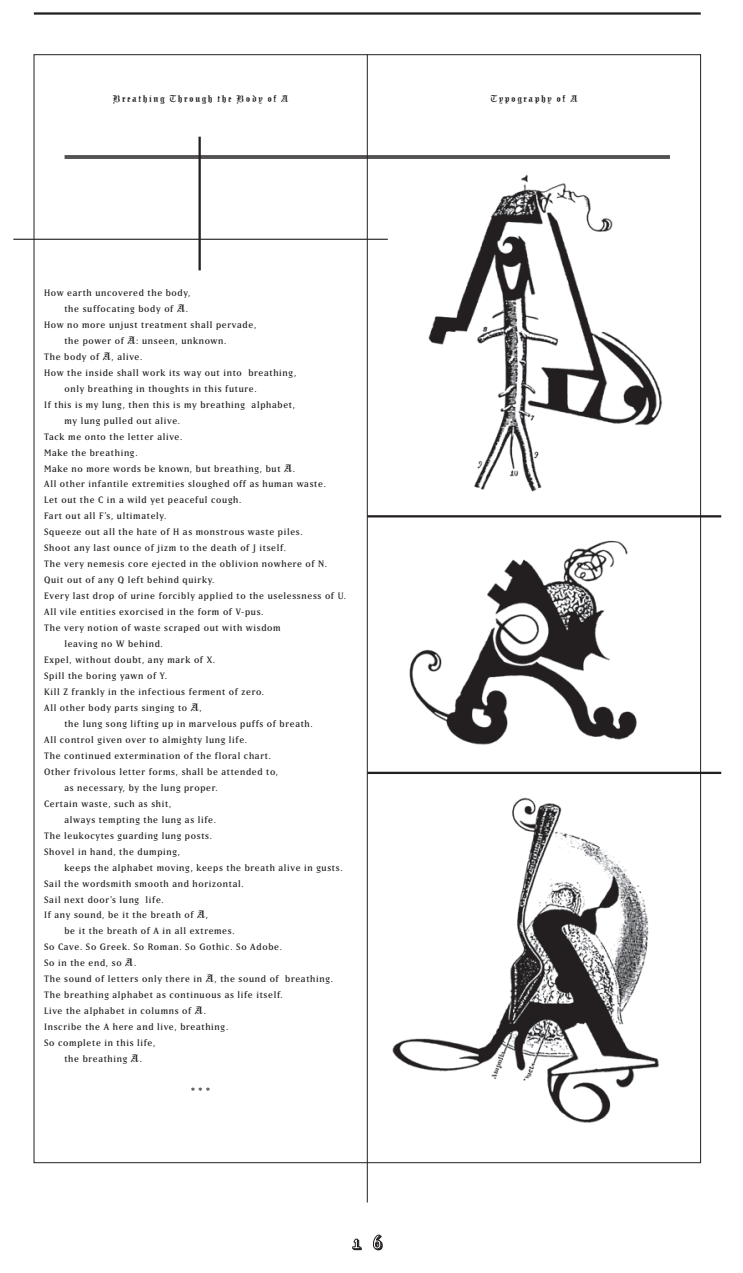

The resultant forms, sometimes curious anomalies, sometimes floral beauties, inevitably challenge the conception of typography today.

In 1994, in Emigre, Schorn presented a long poem titled "Breathing Through the Body of A", which he had written in response to a project set by Edward Fella - another key figure in the exploration of typographic hybrids (Schorn 1994: 15-20). In an afterword, Schorn explains that Fella had asked the students to imagine a typography of the future by giving it a name, dates, an explanation, a body of work, an aesthetic, an attitude and a philosophy. Schorn responded with a collection of fictionalized historical fragments from the rubble of the future after an unspecified disaster has wiped out almost all traces of the alphabet except for the letter $A$, and left the traumatized survivors unable to speak or write (dysphasia indeed). The letter A then becomes the starting point for a new language - " $A$ is everything. $A$ is all. $A$ is the all beginning./Here, $A$ has become the body. $A$ is breathing" (ibid.: 15). 
Schorn's poem is accompanied by 15 versions of the letter $A$, each one collaged from an array of elements. Many of these fragments are indeterminate, though body parts occur often (thumb, breast, head, foot, various organs) and sections of assorted utilitarian devices can also be discerned (spoon, scissors, safety pin). Thanks to these dated-looking devices and many other ornamental flourishes, the letters appear to be antique, as though they might have been the outcome of some classic surrealist procedure in the 1930s - the surrealists always preferred to use outmoded rather than contemporary source material. Nevertheless, the letters resemble nothing in the surrealist canon, while their framing within the pages of a hyper-contemporary design and type magazine anchors them firmly to the digital present (as it was then). The 15 specimens anatomized by Schorn are more than enough, though, to suggest that $A$ - like any letter of the alphabet - has the potential for limitless conceptual reinterpretation and remodelling, and that in certain circumstances a letter could even become the seed of a new culture.

\section{NOTES}

1. For an introduction to deconstruction, see: Christopher Norris, Deconstruction: Theory and Practice, London and New York: Routledge, 1991 (revised edition). For the concept's source, see: Jacques Derrida, On Grammatology, Baltimore and London: Johns Hopkins University Press, 1997 (corrected editon). For a discussion of deconstruction in relation to typography and graphic design, see: Ellen Lupton and Abbott Miller, "Deconstruction and Graphic Design" in Design Writing Research: Writing on Graphic Design, London and New York: Phaidon, 1999, pp. 3-23, and Rick Poynor, No More Rules: Graphic Design and Postmodernism, London: Laurence King Publishing, 2003, pp. 38-69.

2. For Dysphasia, see Heller and Fink, 1997, p. 35.

\section{REFERENCES}

Barnbrook, Jonathan. (2007). Barnbrook Bible: The Graphic Design of Jonathan Barnbrook. London: Booth-Clibborn Editions.

Eluard, Paul \& Breton, André. (1938). Dictionnaire abrégé du surréalisme. Paris: Galerie Beaux-Arts.

Heller, Steven, \& Fink, Anne. (1997). Faces on the Edge: Type in the Digital Age. New York, NY: Van Nostrand Reinhold.

Johnson, Philip, \& Wigley, Mark. (1988). Deconstructivist Architecture. Boston, Mass.: Museum of Modern Art/Little Brown and Company.

Kinross, Robin. (2004). Modern Typography: An Essay in Critical History (2nd ed.). London: Hyphen Press.

LeWitt, Sol. (1967). Paragraphs on conceptual art. Artforum, 5(10), 79-83, Summer. Reprinted in Charles Harrison and Paul
Wood (eds.) (1992). Art in Theory 1900-1990: An Anthology of Changing Ideas (p. 834). Oxford: Blackwell.

Massin, (Robert). (1970). Letter and Image. London,: Studio Vista.

Poynor, Rick. (2007). Dark Tools of Desire, Eye, 63(16), Spring.

Poynor, Rick. (2010). Uncanny : Surrealism and graphic design. Brno: Moravská Galerie.

Poynor, Rick, \& Booth-Clibborn, Edward (Eds.) (1991). Typography Now: The Next Wave. London, England: Booth-Clibborn Editions.

Rouard-Snowman, Margo. (1993). Roman Cieslewicz. London: Thames \& Hudson.

Schorn, Brian. (1994) Breathing Through the Body of A: A Typographical Approach for the Future, Emigre, 32.

Willen, Bruce, \& Strals, Nolen. (2009). Lettering \& Type (1st ed.). New York: Princeton Architectural Press.

\section{CORRESPONDENCE}

Rick Poynor, Royal College of Art, Kensington Gore, London, SW7 2EU, United Kingdom.

E-mail: rpoynor@btinternet.com

Published online 27 January, 2014

ISSN 1749-3463 print/ ISSN 1749-3471

(C) 2014 Artifact

Copyright to illustrations in this article resides with the creator unless otherwise noted. Artifact publishes illustrations in accordance with commonly acknowledged fair use of visual materials for non-commercial research purposes. Creators who feel that publication is in violation of copyright or fair use should contact the editors. 